\title{
METHODS FOR MOLECULAR SURVEILLANCE OF INFLUENZA USED IN MACEDONIA
}

\section{Golubinka Bosevska ${ }^{1}$, Elizabeta Janceska ${ }^{1}$, Gordana Kuzmanovska ${ }^{1}$, Vladimir Mikik ${ }^{1}$, Nikola Panovski ${ }^{2}$}

\author{
${ }^{1}$ Institute of Public Health of the Republic of Macedonia, Skopje, R. Macedonia \\ ${ }^{2}$ Institute of Microbiology and Parasitology, Medical Faculty, Skopje, R. Macedonia \\ Corresponding Author: Golubinka Bosevska, Institute of Public Health of the Republic of Macedonia, Skopje,
} R. Macedonia, Tel.: + 389 (0)2 31250 44; Email: golubinka@yahoo.com

\begin{abstract}
The aim: To present and compare different Nucleic Acid Testing assays used for laboratory diagnosis of influenza virus infection in our country.

Materials and methods: Respiratory samples used were nose and throat swabs. The RNA extraction was performed with a QIAamp viral RNA kit. During the season 2009-2010 the first 25 samples were tested with: conventional gel-based RT-PCR and CDC rtRT-PCR using published specific matrix and HA gene primers and probes for influenza virus typing and subtyping.

Results: Of 25 samples tested with conventional RT-PCR 7(28\%) were positive for influenza A, but negative for $\mathrm{A} / \mathrm{H} 1$ seasonal and $\mathrm{A} / \mathrm{H} 3$. Retested with rtRT-PCR 9(36\%) were positive for influenza A, $8(32 \%)$ were positive for $\mathrm{A} / \mathrm{H} 1 \mathrm{pdm}$ and $1(4 \%)$ was $\mathrm{A} / \mathrm{H} 3$. Two samples positive with $\mathrm{rtRT}-\mathrm{PCR}$ for influenza A were negative with RT-PCR. The sensitivity of the RT-PCR in comparison with rtRT-PCR is $100 \%$ and the specificity is $88.89 \%$. Positive predictive value for RT-PCR is $77.78 \%$, and negative predictive value is $100 \%$. RT-PCR is a four-step and rtRT-PCR a one-step procedure. The turn-around time of RT-PCR is 6 hours and for rtRT-PCR it is 2 hours.

Discussion and conclusion: For surveillance purposes nose and throat swabs are the more easy and practical to collect. It was proved that RT-PCR is too laborious, multi-step and time-consuming. The sensitivity of both assays is equal. The specificity of rtRT-PCR is higher. NAT assays for detection of influenza viruses have become an integral component of the surveillance programme in our country. They provide a fast, accurate and sensitive detection of influenza.
\end{abstract}

Key words: influenza, molecular surveillance.

\section{Introduction}

Influenza viruses are the most common viral respiratory pathogens among outpatients presenting with ILI (influenza-like illness), as well as the reason for hospitalization of patients with severe viral infection and secondary bacterial pneumonia. Reassortant influenza A viruses can cause disease that is severe and widespread, such as the first pandemic of the $21 \mathrm{st}$ Century caused by a novel H1N1 influenza A virus that first emerged in March 2009 in Mexico and Southwestern USA $[1,2]$
This pandemic highlights the urgent need for fast, accurate and sensitive detection of influenza A viruses and their rapid subtyping within surveillance and diagnostic networks. Early detection of influenza virus infection is crucial for containing the disease and prevention of its transmission [3].

\section{Objective}

The aim is to present and compare different Nucleic Acid Testing (NAT) assays used for laboratory diagnosis of influenza virus infection in our country. 


\section{Materials and methods}

Respiratory samples used for influenza testing were nose (collected from each nostril) and throat swabs. The RNA extraction was performed according to the manufacturer's protocol included in the QIAamp viral RNA kit (Qiagen, Valencia, CA, and USA). Starting with a $140 \mu \mathrm{L}$ sample RNA was bound to a silica matrix followed by a spin column purification with a final eluate of $60 \mu \mathrm{l}$ RA. Two PCR methods were used: conventional gel-based Reverse transcriptase (RT) reaction followed by Polymerase chain reaction (PCR) for the detection of influenza A viruses (RT-PCR) and real-time RT-PCR (rtRT-PCR).

The conventional RT-PCR assay was conducted using a four -step RT-PCR as follows: reverse transcriptase reaction was performed using a First Strand cDNA Synthesis kit (Fermentas) with a random hexamer primer $(0.2 \mu \mathrm{g} / \mu \mathrm{L}), 5 \mathrm{X}$ reaction buffer, DEPC treated water, $10 \mathrm{mM}$ dNTP Mix, Ribolock Ribonuclease inhibitor $(20 \mathrm{U} / \mu \mathrm{L})$, and RevertAid M MuLV RT (reverse transcriptase $200 \mathrm{U} / \mu \mathrm{L}$ ). Protocol for reverse transcription: add $1 \mu \mathrm{L}$ hexamer primer and $9 \mu \mathrm{L}$ DEPC treated water to $2 \mu \mathrm{L}$ RNA, centrifugation 15 seconds, incubation on $70^{\circ} \mathrm{C}$ for $5 \mathrm{~min}$, cooling on $4^{\circ} \mathrm{C}$. Duration of protocol is 15 minutes. Add $4 \mu \mathrm{L} 5 \mathrm{X}$ reaction buffer, $1 \mu \mathrm{L}$ Ribonuclease inhibitor and $2 \mu \mathrm{L}$ dNTP mix. Incubation on $25^{\circ} \mathrm{C}$ for $5 \mathrm{~min}$. The duration of the protocol is 8 minutes. Add $1 \mu$ L RevertAid M MuLV RT. Thermocycling: $25^{\circ} \mathrm{C}$ for $10 \mathrm{~min}, 42^{\circ} \mathrm{C}$ for $60 \mathrm{~min}, 70^{\circ} \mathrm{C}$ for 10 $\min , 4^{\circ} \mathrm{C}$ for $5 \mathrm{~min}$. The duration of this protocol is $1 \mathrm{~h}$ and 30 minutes. The generated cDNA was used as input in PCR reaction or kept at $20^{\circ} \mathrm{C}$ until use.

A polymerase chain reaction was carried out with primer pairs for targeting different regions such as for Influenza A / MA generating a PCR product of $219 \mathrm{bp}$, for Influenza $\mathrm{A} / \mathrm{H} 1$ generating a $\mathrm{PCR}$ product of $334 \mathrm{bp}$, for Influenza $\mathrm{A} / \mathrm{H} 3$ generating a $\mathrm{PCR}$ product of $414 \mathrm{bp}$ [4]. PCR mix for each primer set: $5 \mu \mathrm{L}$ primer $1,5 \mu \mathrm{L}$ primer 2, $5 \mu \mathrm{L}$ Amplitaq gold buffer, $1 \mu \mathrm{L}$ dNTP mix, $5 \mu \mathrm{L} \mathrm{MgCl}_{2}, 1 \mu \mathrm{L}$ Amplitaq gold polymerase, 25,5 $\mu \mathrm{L} \mathrm{ddH}_{2} \mathrm{O}$. Add $2,5 \mu \mathrm{L}$ cDNA to the PCR mix. The amplification condition consisted of $95^{\circ} \mathrm{C}$ for 10 minutes followed by 35 cycles of $95^{\circ} \mathrm{C}$ for 0.5 minutes, $45^{\circ} \mathrm{C}$ for 1 minutes, $72^{\circ} \mathrm{C}$ for 2 minutes. A final extension step at $72^{\circ} \mathrm{C}$ for 10 minutes was performed. The duration of the protocol is $3 \mathrm{~h}$. The assay was performed on a PTC-100 Peltier Thermal Cycler (MJ Research).

Ten microlitres of amplified PCR product was analyzed on a $1.5 \%$ agarose gel in a TBE $(1 \mathrm{x})$ buffer containing ethidium bromide. $10 \mu \mathrm{L}$ of marker was added to first and last lane. The gel was run for 55 minutes at 120 volt. The DNA was visualized using a UV tran sil lumi nator.

The CDC real-time RT-PCR (rtRT-PCR) assay directed at matrix gene sequences of influenza $\mathrm{A}$ and $\mathrm{B}$, and hemagglutinin gene sequences for influenza A subtypes - H1 pandemic, H3 seasonal, H1 seasonal were used. The reaction was performed according to published laboratory diagnostic protocol (World Health Organisation, CDC Protocol of real-time RTPCR for swine influenza A (H1N1), 28 April 2009, the WHO Collaborating Centre for influenza at CDC Atlanta, United States of America) [5]. Diagnostic kits were globally available via the WHO Global Influenza Surveillance Network (GISN) [6]. The duration of protocol is 2 hours. The assay was performed on an IQ5 (Biorad).

A sample is considered positive if results from tests using one or two different PCR targets (e.g. primers specific for universal $M$ gene; or universal $\mathrm{M}$ gene and $\mathrm{A} / \mathrm{H} 1 \mathrm{~N} 1 \mathrm{pdm}$ haemagglutinin gene; or universal $\mathrm{M}$ gene and $\mathrm{A} / \mathrm{H} 3 \mathrm{~N} 2$ haemagglutinin gene) are positive. If RT-PCR for multiple haemagglutinin (HA) targets (e.g. $\mathrm{A} / \mathrm{H} 3$, and $\mathrm{A} / \mathrm{H} 1 \mathrm{~N} 1 \mathrm{pdm}$ ) give positive results in the same specimen, the possibility of PCR contamination should first be excluded by repeating the PCR procedure using a new RNA extract from the original specimen or an RNA extract from another specimen.

During the season 2009-10 in the period from 30.04.2009 (18 week) to 18.05.2010 (20 week) a total of 3010 samples were tested for influenza. First 25 samples from first suspect for influenza patients were tested with conventional RT-PCR and rtRT-PCR.

\section{Results}

Of 25 samples tested for influenza with conventional RT-PCR 7 (28\%) samples were positive for influenza $\mathrm{A}$, but negative for $\mathrm{A} / \mathrm{H} 1$ 
seasonal and $\mathrm{A} / \mathrm{H} 3$. All 25 samples were retested with rtRT-PCR. Nine $(36 \%)$ were positive for influenza A. $8(32 \%)$ of them were positive for H1pdm and one (4\%) was H3. Two samples positive with rtRT-PCR for influenza A were negative with conventional RT-PCR. (Table 1. Number of samples tested with conventional RT-PCR and real time RT-PCR)

The sensitivity of the conventional RTPCR in comparison with rtRT-PCR is $100 \%$ and the specificity is $88.89 \%$. The positive predictive value for RT-PCR is $77.78 \%$, and the negative predictive value is $100 \%$.

Table 1

Number of samples tested with conventional RT-PCR and real-time $R T$ - $P C R$

\begin{tabular}{|l|c|c|}
\hline & RT-PCR & rtRT-PCR \\
\hline Influenza A & $\mathbf{7}$ & $\mathbf{9}$ \\
\hline H1 seasonal & 0 & 0 \\
\hline H3 & 1 & 1 \\
\hline H1pdm & 0 & 8 \\
\hline Negative & $\mathbf{1 8}$ & $\mathbf{1 6}$ \\
\hline Total & $\mathbf{2 5}$ & $\mathbf{2 5}$ \\
\hline
\end{tabular}

Of 3010 samples tested for influenza with rtRT-PCR, 1632 (54.2\%) samples were positive for influenza A. 1556 (or $95.34 \%$ of the positive samples for influenza A) were $\mathrm{A} / \mathrm{H} 1 \mathrm{pdm}$ and one was H3. (Table 2. Total number of samples tested with real time RTPCR during season 2009-10).

Table 2

Total number of samples tested with real time RT-PCR during season 2009-10

\begin{tabular}{|c|c|}
\hline rtRT-PCR & $\begin{array}{c}\mathbf{2 0 0 9}-\mathbf{1 0} \\
\mathbf{( 3 0 . 0 4 . 2 0 0 9 - 1 8 . 0 5 . 2 0 1 0 )} \\
\text { season }\end{array}$ \\
\hline Influenza A & 1632 \\
\hline H1pdm & 1556 \\
\hline H3 & 1 \\
\hline Inf B & 0 \\
\hline Negative & 1378 \\
\hline Total & 3010 \\
\hline
\end{tabular}

Conventional RT-PCR for influenza is a multi-step or four-step procedure including three steps in the process of reverse transcription followed by PCR. The turn-around time of the assay from isolated RNA until the final reading of the results is 6 hours. The time needed for reverse transcriptions is 2 hours; for PCR is 3 hours and 1hour for electrophoresis. The number of samples for electrophoresis is limited from 20 to 30 in one run depending on the comb tooth. In our lab we can put 22 samples for influenza screening in two rows on one gel, or 11 samples for typisation.

rtRT-PCR is a one-step procedure including reverse transcription, PCR and detection of the products. The turn-around time is 2 hours from isolated RNA until the final reading of the results. The number of samples included in one run is 48 for screening or 24 for screening and subtypisation.

\section{Discussion}

In response to the H1N1 pandemic in 2009, most countries have enhanced and strengthened their virological surveillance systems. Current diagnostic methods include virus isolation, antigen detection, and serology. Major limitations of these techniques include prolonged time to completion, subjective evaluation, low sensitivity, and low specificity. It is critical for diagnostic laboratories all over the world to have access to assays employing rapid, reliable and affordable technology, which are able to differentiate the H1N1pdm virus from currently circulating influenza viruses. Use of nucleic acid amplification techniques (NAT) has made sensitive diagnosis of influenza virus infection feasible, with the possibility of type determination. NAT has been employed by many health officials for tracking, detecting and characterizing $\mathrm{H} 1 \mathrm{~N} 1 \mathrm{pdm}$ virus infection [3, 7-9].

Surveillance was aimed at contributing to the detection of influenza viruses and to determining the predominant circulating strain. A challenge for laboratories is ensuring that their assays are accurate for influenza viruses. Genetic variation may particularly affect nucleic acid testing [10].

The type of specimens is one of the variables important in the successful detection of influenza viruses. In our surveillance we used upper respiratory tract samples such as combined nose and throat swabs, as they are the most easy and practical samples to collect and this requires no additional devices. Testing 
of nasal swabs detected all respiratory viruses including influenza at rates comparable to those of nasopharyngeal aspirates [11]. Although nasopharyngeal aspirates and nasal washes are generally considered the specimens of choice for the detection of respiratory viruses, they are rarely done because they cause discomfort and the risk of aspiration. The present practice in several European countries for influenza viruses includes the collection of both nasal and throat samples that are put in the same vial for transportation to the laboratory [12].

Since the specimen quality, timing, and transportation conditions may be less critical for nucleic acid testing than for culture or antigen detection, as viable virus and intact infected cells need not be preserved, they were not a subject of our analysis [13-15].

We used a QIAamp viral RNA mini kit as convenient for extraction of viral RNA and it has been documented to be reproducible and sensitive for viral RNA. It is suitable for routine use, for the processing of large numbers of samples and it easy to perform [16].

Depending on primer selection, NAT may be type- or sub-type specific. The primer pairs are designed on the basis of the known sequences of different influenza genes of interest, and therefore will specifically detect RNA of influenza virus or only one subtype. Most published RT-PCR strategies for typing and subtyping influenza A viruses are based on the matrix and HA segments respectively. The reason for not choosing the neuraminidase gene as the target gene for the real-time or gel-based RT-PCR assays is based on the knowledge that the neuraminidase gene is not highly conserved among influenza A viruses when compared with the matrix gene [17]. Primers that target matrix gene sequences that are relatively conserved across all influenza A viruses detect all influenza subtypes [3]. Because of the conserved nature of the matrix gene segment among different type A influenza viruses, specific matrix gene primers and probes are designed for influenza virus typing (i.e., distinguishing type $A$ and type B influenza virus) in human samples. Molecular subtyping of an unknown influenza A virus is difficult owing to the highly variable sequences of the 16 different HA and nine different NA gene segments [13, $14,18,19]$.
In this study, we used a four-step conventional gel-based RT-PCR assay and onestep rtRT-PCR targeting the matrix gene of the influenza viruses. The reverse transcription polymerase chain reaction (RT-PCR) which allows purified influenza viral RNA was first reverse transcribed into complementary DNA (cDNA), the cDNA was then amplified with a pair of oligonucleotide-specific primers and detected. We used a four-step conventional gel based RT-PCR for performing the first reverse transcription in three steps followed by PCR [4]. The RT-PCR products were detected at the end of the reaction. With real time RT-PCR, products are detected as amplification is ongoing. The rt RT-PCR assays used in influenza A virus surveillance and diagnosis are based on a TaqMan approach, in which a probe is designed to hybridize to an internal region of the PCR product so that the highest sensitivity and specificity can be achieved during the PCR amplification [20].

The CDC developed a rtRT-PCR protocol for 2009 H1N1 influenza A virus detection shortly after the emergence of the outbreak. A one-step rtRT-PCR approach, which targets the matrix gene of the novel influenza $\mathrm{A} / \mathrm{H} 1 \mathrm{~N} 1$, was designed and successfully used to detect novel H1N1 in clinical specimens and did not cross-react with seasonal influenza A, subtypes $\mathrm{H} 1 \mathrm{~N} 1$ and $\mathrm{H} 3 \mathrm{~N} 2$ viruses and swine influenza A (H1N1) [5, 21, 22]. The CDC rtRT-PCR Flu Panel assay was approved by the FDA for clinical influenza test applications and was rapidly distributed to research and clinical laboratories worldwide to ensure that information on novel influenza A H1N1 virus infection was released in a timely and accurate manner in the international community.

In our surveillance study it was proved that the gel-based RT-PCR is too laborious, multi-steps are needed and it is time-consuming in comparison with rtRT-PCR. Although we did not have any false positive result, in multi-step PCR assays cross-contamination is well known and possible. The possibility of cross contamination during rtRT-PCR is less possible, but cannot be completely excluded. An alternative explanation for false-positive results could be unspecific primer annealing and subsequent amplification [23]. 
According to our results the sensitivity of both assays is equal. Contrary to other studies where the gel-based assay was less sensitive than the real-time RT-PCR assay and the sensitivity and specificity of the real-time RT-PCR relative to the gel-based RT-PCR was $100 \%$ and $95 \%$, respectively $[17,24]$. The diagnostic specificity of conventional RT-PCR is $88.89 \%$, confirmed by other studies as well [25]. The two discordant samples were positive by the realtime RT-PCR and negative by the RT-PCR, a discrepancy most likely due to the higher sensitivity of the real-time RT-PCR assay when compared to the gel-based RT-PCR. A lower viral load in samples could be associated with false negatives in conventional RT-PCR [26].

The positive predictive value (the proportion of patients with positive results who have influenza) of an RT-PCR is lowest when influenza activity is low. The negative predictive value (the proportion of patients with negative results who do not have influenza) of an RTPCR is highest when influenza activity is low [25].

Limitations: 1 Timiing of the specimen collection is not always early in the disease when the viral load is maximum; 2. Evaluation of the CDC assay for detection of influenza B was not feasible due to the low virus prevalence during the test period; 3 . We did not determin bigger discrepancies between conventional RT-PCR and rtRT-PCR, most likely because of the small number of samples investigated.

\section{Conclusion}

NAT assays for the detection of influenza viruses have become an integral component of the human surveillance programme in our country. They provide fast, accurate and sensitive detection and diagnosis for influenza surveillance. In the emergence of the pandemic influenza A/H1N1pdm in 2009/2010, the realtime RT-PCR method became the primary assay for rapid and accurate identification and subtyping of influenza viruses for surveillance, outbreak management, diagnosis and treatment. Laboratories should be capable of identifying influenza viruses and novel influenza subtypes. Due to the constant evolution of influenza A viruses, diagnostic assays will need to be continually updated in the future. It is suitable and effective to use standardized molecular detection protocols and systems for influenza virus diagnosis and surveillance worldwide.

\section{REFERENCES}

1. Peiris JS, Poon LL, Guan Y. Emergence of a novel swine-origin influenza A virus (S-OIV) H1N1 virus in humans. J. Clin. Virol. 2009; 45(3): 169-173.

2. Vijaykrishna D, Poon LLM, Zhu HC, et al. Reassortment of pandemic H1N1/2009 Influenza A virus in swine. Science. 2010; 328 (5985), 1529.

3. Petric M, Comanor L, Petti CA. Role of the laboratory in diagnosis of influenza during seasonal epidemics and potential pandemics. J Infect Dis. 2006; 1: 194 (Suppl 2): S98-110.

4. ESWI Practical Course Influenza, June 8-11, 2009, Department of Virology, Erasmus MC, Rotterdam.

5. World Health Organization. CDC Protocol of real time RTPCR for swine influenza A (H1N1), version 2009. Available from

http://www.who.int/csr/resources/publications/s.wine flu/CDCrealtimeRTPCR_SwineH1Assay2009_20090430.pdf)

6. Evolution of a pandemic: A(H1N1) 2009, April 2009-March 2010, WHO. Available from http://whqlibdoc.who.int/publications/2010/9789241 599924_eng.pdf.

7. Blair PJ, Wierzba TF, Touch S, et al. Influenza epidemiology and characterization of influenza viruses in patients seeking treatment for acute fever in Cambodia. Epidemiol. Infect. 2009; 138(2): 199-209.

8. Kelly H, Grant K. Interim analysis of pandemic influenza (H1N1) 2009 in Australia: surveillance trends, age of infection and effectiveness of seasonal vaccination. Euro Surveill. 2009; 14(31) pii: 19288.

9. Jamieson DJ, Honein MA, Rasmussen SA, et al. H1N1 2009 influenza virus infection during pregnancy in the USA. Lancet. 2009; 374 (9688): 451-458.

10. Wang R, Taubenberger JK. Methods for molecular surveillance of influenza. Expert Rev Anti Infect Ther. 2010; 8(5): 517-527.

11. Heikkinen T, Marttila J, Salmi AA, Ruuskanen O. Nasal Swab versus Nasopharyngeal Aspirate for Isolation of Respiratory Viruses. J Clin Microbiol. 2002; 40(11): 4337-4339.

12. Tumova B, and the European Scientific Working Group on Influenza. Survey on influenza laboratory diagnostic and surveillance methods in Europe. Eur J Epidemiol. 2000; 16: 217-222.

13. Ellis JS, Fleming DM, Zambon MC. Multiplex reverse transcription-PCR for surveillance of influenza A and B viruses in England and Wales in 
1995 and 1996. J Clin Microbiol. 1997; 35: 20762082.

14. Schweiger B, Zadow I, Heckler R, et al. Application of a fluorogenic PCR assay for typing and subtyping of influenza viruses in respiratory samples. J Clin Microbiol. 2000; 38: 1552-1558.

15. Carman WF, Wallace LA, Walker J, et al. Rapid virological surveillance of community influenza infection in general practice. BMJ. 2000; 321: 736-737.

16. Fransen K, Mortier D, Heyndrickx L, et al. Isolation of HIV-1 RNA from plasma: evaluation of seven different methods for extraction (part two). J Virol Methods. 1998; 76 (1-2): 153-157.

17. Ma W, Oberst R, Li X, et al. Rapid detection of the pandemic 2009 H1N1 virus M gene by real-time and gel-based RT-PCR assays. Influenza and Other Respiratory Viruses. 2010; 4(6), 397-403.

18. Dugan VG, Chen R, Spiro DJ, et al. The evolutionary genetics and emergence of avian influenza viruses in wild birds. PLoS Pathog. 2008; 4(5): e1000076.

19. Stockton J, Ellis JS, Saville M, et al. Multiplex PCR for typing and subtyping influenza and respiratory syncytial viruses. J Clin Microbiol. 1998; 36: 2990 2995.

20. Di Trani L, Bedini B, Donatelli I, et al. A sensitive one-step real-time PCR for detection of avian influenza viruses using a MGB probe and an internal positive control. BMC Infect. Dis. 2006; 6: 87.

21. Carr MJ, Gunson R, Maclean A, et al. Development of a real-time RT-PCR for the detection of swinelineage influenza A (H1N1) virus infections. J Clin Virol. 2009; 45(3): 196-199.

22. Whiley DM, Bialasiewicz S, Bletchly $\mathrm{C}$, et al. Detection of novel influenza $\mathrm{A}(\mathrm{H} 1 \mathrm{~N} 1)$ virus by realtime RT-PCR. J Clin Virol. 2009; 45(3): 203-204.

23. Herrmann B, Larsson C, Zweygberg BW. Simultaneous Detection and Typing of Influenza Viruses $\mathrm{A}$ and $\mathrm{B}$ by a Nested Reverse Transcription-PCR: Comparison to Virus Isolation and Antigen Detection by Immunofluorescence and Optical Immunoassay (FLU OIA). J Clin Microbiol. 2001; 39(1): 134-138.

24. Agrawal AS, Sarkar M, Chakrabarti S, et al. Comparative evaluation of real-time PCR and conventional RT-PCR during a 2 year surveillance for influenza and respiratory syncytial virus among children with acute respiratory infections in Kolkata, India, reveals a distinct seasonality of infection. J Med Microbiology. 2009; 58: 1616-1622.

25. Özdemir M, Yavru S, Baysal B. Comparison of the Detection of Influenza A and B Viruses by Different Methods. J Inter Med Res. 2012; 40: 2401-2408.

26. Van Elden LJ, Van Kraaij NM, Hendriksen K A, et al. Polymerase chain reaction is more sensitive than viral culture and antigen testing for the detection of respiratory viruses in adults with hematological cancer and pneumonia. Clin Infect Dis. 2002; 34: 177-183.
Резиме

\section{МЕТОДИ ЗА МОЛЕКУЛАРНО СЛЕДЕЊЕ НА ИНФЛУЕНЦА ВО МАКЕДОНИЈА}

\section{Голубинка Бошевска ${ }^{1}$, Елизабета Јанческа ${ }^{1}$, Гордана Кузмановска ${ }^{1}$, Владимир Микиќ, Никола Пановски ${ }^{2}$}

${ }^{1}$ Институт за јавно здравје на Република Македонија, Скопје, Р. Македонија

${ }^{2}$ Институт за микробиологија и паразитологија, Медицински факултет, Скопје, Р. Македонија

Цел: Да се презентираат и споредат различните тестови за детекција на нуклеинска киселина што се користат во лабораториската дијагноза на инфлуенца вирусна инфекција во нашата земја.

Майеријал и мейоди: Респираторни примероци за анализа беа брис од грло и нос. Изолацијата на PHK е направена со QIAamp viral RNA kit. За време на сезоната 2009-2010, првите 25 теста се тестирани со: конвенционален на база на гел RT-PCR и CDC rtRT-PCR со употреба на објавени специфични прајмери и проби за матрикс и НА гените за типизација и суптипизација на инфлуенца вирусите.

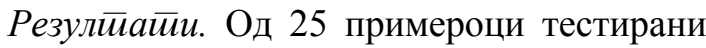
со конвенционален RT-PCR 7(28\%) биле позитивни на инфлуенца А, но негативни на A/ceзонски и A/H3. Ретестирани co rtRT-PCR 9(36\%) беа позитивни на инфлуенца А, од нив $8(32 \%)$ беа позитивни на A/H1pdm и 1(4\%) бешеА/ H3. Два примерока позитивни за инфлуенца А со rtRT-PCR беа негативни со RT-PCR. Сензитивноста на RT-PCR во споредба со rtRT-PCR e $100 \%$, а специфичноста е $88,89 \%$. Позитивната предиктивна вредност на RT-PCR е $77,78 \%$, a негативната предиктивна вредност е $100 \%$. RTPCR е процедура во четири чекори, a rtRT-PCR е во еден чекор. Времетраењето на RT-PCR е шест часа, а на rtRT-PCR е два часа.

Дискусија и заклучок: За целите на следење на инфлуенца, брисевите на грло и нос се полесни и попрактични за земање. Се докажа дека RT-PCR е потежок за изведување, со многу чекори, и потребно е повеќе време. Сензитивноста на двата теста е иста. Специфичноста на rtRT-PCR е повисока. Тестовите за детекција на нуклеинска киселина на инфлуенца вирусите станаа интегрален дел на програмата за следење во нашата земја. Тие овозможуваат брза, сигурна и осетлива детекција на инфлуенца.

Клучни зборови: инфлуенца, молекуларно следење. 